\title{
Health and Nutritional Status of Female Garment Workers in Bangladesh: A Critical Analysis
}

Md. Riaduzzaman

${ }^{1}$ Lecturer and Head (In-Charge), Department of Law, Daffodil International University, Dhaka, Bangladesh

\begin{abstract}
Garment industry is the main economic sector of Bangladesh. This labor intensive sector has developed here rapidly because of its cheap labor. The most notable feature of this industry is its heavy use of women workers, an estimated $70-80 \%$ of those employed in the industry are women. Two groups of women have been particularly engaging in these jobs; women in low income male headed households and women heads of household. Thus impoverishment and the absence of a male breadwinner are two characteristics of the wage seeking women. The status of health enjoyed by the people largely depends upon the overall socio-economic development of the country. In Bangladesh the extremely low income of the majority of the people pushes health care to low priority. The situation of female health is much below the condition of total population because of women has to bear the brunt of poverty more than her male counterpart.
\end{abstract}

Keywords: Garment worker, Women Health, Nutrition, Malnutrition, Poverty.

\section{INTRODUCTION}

Garment industry is the main economic sector of Bangladesh at present. This labor intensive sector has developed here rapidly because of its ordinary technology, cheap labor and small area. Before liberation in 1970 there was only one garments factory in Bangladesh. Since the 1980's an export based garment industry has mushroomed in Bangladesh. Now the number of garments in Bangladesh is 3300 (about). Seventy six percent of total export of Bangladesh is garment oriented. Bangladesh exports 73 items of garment product. Nearly $70 \%$ of the workers have rural background. Perhaps the most notable feature of this industry is its heavy use of women workers, an estimated $70-80 \%$ of those employed in the industry are women. Two groups of women have been particularly likely to be engaging in these jobs; women in low income male headed households and women heads of household. Thus impoverishment and the absence of a male breadwinner are two characteristics of the wage seeking women. The status of health enjoyed by the people largely depends upon the overall socio-economic development of the country. In developing country like Bangladesh the extremely low income of the majority of the people pushes health care to low priority. The situation of female health is much below the condition of total population because of a woman has to bear the brunt of poverty more than her male counterpart. Malnutrition is very common among the women of our country.

Over the last few decades Bangladesh is experiencing large scale rural-urban migration due to increase in the level of poverty, joblessness etc. due to poor economic activities in the rural areas. Factors like cyclone river erosion, flood, famine etc. also rendering many people homeless and economically distorted and eventually forcing them to migrate to the cities for shelter, security and protection. On arrival in the city center they start searching for jobs to survive. The expansion of garments sector in recent years have opened a new avenue for these poor, displaced population group, particularly for women for survival. The participation of women in wage labor is considered a direct response to increasing poverty. Their wage is frequently used as a means of adjustment to insufficient family income. Eighty percent of the total garments workers in the country are estimated to be female and 50\% of them are adolescent girl. Reports on the nutritional situation of garment worker in the country are very scares.

Malnutrition in Bangladesh is a well-documented problem of the public health significance. Women's participation in the job market is becoming a necessity for a better lifestyle. At present $41 \%$ of the total labor force in the country is female. The recent entrance of women in the urban formal sector viz. 
garments manufacturing, the majority of these women workers are rural migrant. Usually the young unmarried girl and their wage are frequently used as a means of adjustment to insufficient family income.

\section{OBJECTIVES OF THE STUDY}

The following specific objectives are set forth in order to give proper directions of the study.

- To see their food consumption pattern.

- To measure the nutritional status of the female workers.

- To identify the reasons of not taking nutritious food if not take.

- To explore the actual awareness about nutritional needs among female garment worker and the experience of them.

\section{LIMITATIONS OF THE STUDY}

Considering time and resources available the researcher had to face certain limitations mentioned below:

- The study area was confined to only three garment factory in Gazipur, Bangladesh.

- Access to books, Journals, research paper and other published and unpublished materials were limited.

- The researcher had to depend on the data furnished by the selected respondents.

- Detail map of the study area is not available.

- One of the major difficulties was the time constraint.

\section{METHODOLOGY OF THE STUDY}

The study has followed mainly the analytical approach to describe the present status of the society. It also followed the socio-legal approach considering the research questions. This research has approached two ways of primary data collections. First one is direct interview which known as qualitative primary data. Interviews were conducted with women garment workers. The study has also collected information from case study and structured questionnaire which is called quantitative primary data from the students. The secondary data have been collected from selected garment factories, legislations, books, research papers, journals, reports and news.

\section{Nutritional Status of Bangladeshi Women}

Women's health status and nutritional level is very low in our country. The average weight of Bangladeshi women is about $40.90 \mathrm{~kg}$. Which is less than the mean weight of women in most third world countries. The low weight is a reflection of years of food deprivation. The mean height of Bangladeshi women is 151 centimetres, which is above the critical height of 141 centimetres. A proportion of women (16\%) are below 145 centimetres. 34\% of women are find to be chronically malnourished, their Body Mass Index (BMI) being less than 18.5. One in ten women are find to be overweight or obese (BMI 25 or higher). A women's place of residence, level of education and household wealth quintile are strongly associated with her nutritional status. For example 37 percent of rural women are considered thin $(<18.5)$, compared with $25 \%$ of their urban counterparts. Among division, Sylhet has the highest proportion of women who are thin (48\%) and Khulna the least (29\%). Although Bangladeshi women with children under five years are not getting taller, there is a subsequential improvement in mother's nutritional status as measured by BMI since 1996-1997. The proportion of mother below the cut-off point of BMI of 18.5 continued to drop from 52\% in 1996-97 to $38 \%$ in 2004 a decline of $27 \%$ in less than ten years. Malnutrition, environmental insanitation and shortage of medical services and above all a negative attitude towards female health have been the main causes of poor health of Bangladeshi women.

\section{Poverty and Nutrition}

Nutrition and poverty are two very closely related themes. Many elementary aspects of being poor such as hunger inadequate health care unhygienic living conditions and the stress and strain of precarious living tend to impair a person's nutritional status. In consequence being poor almost 
always means being deprived of full nutritional capabilities the capability to avoid premature mortality to live a life free of avoidable morbidity and to have the energy for work and leisure. Malnutrition in both rural and urban areas is a dimension of poverty. Urban poor are generally considered to be nutritionally at risk and urban poverty is the result of an overflow of rural poverty. Increasing number of rural poor are coming to live in the overcrowded urban slums and squatters with extremely meager or no access to basic services and facilities for a healthy and productive existence.

The study of poverty is therefore very much a study of people's state of nutrition. The axiology of under nutrition widely prevalent among social and economically deprived population groups around the world is associated with a cluster of related after coexistent factors which together constitute what may be termed as "poverty syndrome". The major attributes of which are: 1) Income levels that are inadequate to meet basic needs of food, clothing and shelter. 2) Diet that are quantitatively and after qualitatively deficient. 3) Poor environment, poor access to safe water and sanitation.4) Poor access to health care and 5) Large family size and high levels of illiteracy especially female illiteracy.

\section{Socialization and Female Nutrition}

Mother is the primary teacher of children. She teaches the children how to think how to behave. As our society is patriarchal society, women get less priority in all stage. It is a common belief among poor people that as male are the head of the household and as young boys are growing up and they will become the head of the household at a time they need more and nutritious food. On the other hand as women should stay at home and should not involve in paid employment they need not nutritious food. Though female garments worker are involved in productive income earning work this believes are also present among them. As a result, women's nutritional status is very low in Bangladesh.

\section{Conditions of the Garments Worker}

In reality the condition of garment workers in Bangladesh is very bad. Most of the garment factories do not follow the labor law and ILO conventions. Most of the cases the workers cannot enjoy the weekly holiday. According to the labor law the maximum working hour per day is 10 including the 2 hours overtime. But in most of the cases workers are forced to work 14-16 hours per day. Sometimes they work whole night. Overtime work is compulsory and forceful. There are no housing facilities from the owners. Most of the cases maternity leave is absent. Most of the cases there is no doctor, first aid, sufficient light and ventilation, pure drinking water and toilets for the workers. Most of the factories do not have the day care centers. Most of the cases management do not pay the monthly wage and overtime payment within $7^{\text {th }}$ of the next month. In many cases monthly wages and overtime payment is outstanding for two or three month. Women workers are deprived from equal wage, equal dignity, equal rights and equal promotions.

\section{Sex Segregation in the Garments Industry}

Paul-Majumder, Pratima, Zohir .S.C 1996 reported that Women's involvement in manufacturing industries has traditionally been as part of subsistence where the family is the basic unit of production and consumption. Women's functions in such a production system have been largely viewed as an extension of their domestic function. The transition from subsistence livelihood towards greater participation of family members in wage employment has also witnessed increasing number of women are entering into wage employment in industry primarily in the urban informal and semiformal sections and to a lesser extent in public formal section. But sex segregation is present in work place. Works are divided into two parts on the basis of sex. Within a garments factory tasks are also allocation largely on the basis of sex. Women are virtually all machine operators and helpers in the sewing section. By contrast men are virtually non-operators working either as cutting master or helper in the cutting section, ironer or work in then finishing section. According to the management this division of labor is established by the company rather than due to the choice of workers themselves. Prospective workers usually do not apply for specific job but others for opening unspecified nature. Management than assign the jobs on the basis of sex. They feel that men are more suited for heavy work. The cutting section is fully dominated by men. The cutting master usually has several years of experience. The cutting machine are quit heavy and need steady hands to control it. Some factories have experimented with job changes. They reported that they had tried to have women do the work of cutting helper. But such work has provided to be 100 heavy for them 96 . On the other hand a view existed in the society is that women are naturally better in sewing section. Women are entering in garments industry after facing poverty. Besides this they have low bargaining power to get 
a preferable job. As a result they are engaging in lower status job. Sex segregation is also the cause of different wage level of male and female. Men are recruited in higher level and highly paid job. In contrast women are recruited in low level and low paid job

\section{Status of Female Garment Worker}

In various surveys it is finding that wage employment in then garment industry of Bangladesh has improved the standard of living of female workers significantly. It has been found that wage employment in garment industry has very favorable impact on women's social prestige in the society conjugal life matrimonial relationship fertility and age at marriage sharing of domestic chore decision making etc. Paul -Majumder, Pratima, Zohir .S.C 1996 reported that female workers in the garment industry state they gain tremendous social honor in the society although there is wide spread belief that women lose status if they work in the garment factory. The most common objection is that people talk badly about garment industry. The other negative comment about them are women get spoil in the garment industry and night work spoils women. But views are changing day by day due to social condition. The upper class still views jobs at garments as bad. Paul-Majumder, Pratima, Zohir .S.C 1994 stated that wage employment in garment industry increase women's status in the family. Control over own earning and decision making are important yardstick to measure the social status of the female workers. Women have no control over money they have no say on decision making in the family.

It is usually said that the garment worker's contribution toward family income is very negligible. But in their family male worker contributed $65 \%$ to the family income while a female worker contributed $46 \%$ toward family income. Thus the fact that women are contributing half of family income earned in urban areas is a definite positive charge that has been brought about by the advent of garment industry. Even the lowest earning workers such as sewing helpers contribute about $30 \%$ toward family income. These all suggest that parents are sending their daughters and sons to the garment industry to enhance family income. Not only are they becoming an additional earner but also they are no longer treated as another mouth feed. In this sense especially women view themselves as liberated from the patriarchal family system.

\section{Poverty and Health Status of Garment Workers}

Hasan Sarwar and Ali Easin 1996 reported that it is often believed that the widespread poverty that exists in the country is responsible for the ill health of the garment workers, since most garments worker come from the poverty stricken rural areas of Bangladesh. About 55\% female worker come from the rural areas poverty and prevalence of illness is highly correlated. Illness and diseases are found more prevalent among the members of poor households. This fact suggest that the female workers enter the garment industry with health, since acute exposed them the many dangers like inadequate unbalanced or helplessness etc. with might have affected their health badly. Famida Karim (1993) in her study observed that female garment workers were suffering from negative energy balance. There was significant difference between energy intake and energy expenditure. Hassan and Ahmed (1985) reported that per capita energy intake by urban adolescent girls in Bangladesh was 13\% lower than that of the FAO recommendation. Begum (1993) worked on adolescent girls in Dhaka city and reported that the intake of energy of $29 \%$ of the girls was lower than the requirement. Mannan and Akter (1993) reported that the large number of adolescent girls suffer from various degree of nutritional disorders that result from inadequate or inappropriate intake of specific nutrients. Several studies revealed that the calorie intake of women and adolescent girl of our country was lower than the standard. According to nutrition survey of Bangladesh average calorie intake was much below the standard. Begum (1993) reported that using body mass index data, 25\% adolescent working girls were malnourished and about $2.7 \%$ were obese.

\section{Socio-Economic Characteristics of Women Garments Workers}

Khan Shahin Mohammad and Molla Moonwar Hossain show that available studies indicate that garment workers, particularly female garment workers, are young, unmarried, less education, of rural origin and very poor families. Studies further indicate that most women who work in the Government industry had no prior wage work experience. However, some characteristics of women garment workers have changed over time and some of these characteristics differ between female workers employed in the garment factories located in the DEPZ and those located outside the DEPZ. Major socio-economic characteristics of women garment workers are as follows. 
1) Age: Generally the age a limit of women garment workers is up to 40 years. After 1995, workings of child labor forces in readymade garment industries are significantly reduced due to Government, BGMEA and UNICEF and ILO agreement of eliminating child labor in RMG sector. In 1997 the average age of women garment workers was 20 .

2) Marital status: In readymade garment industries marriage is considered the main constraint of the employer as well as the employee, but still there are about 38 percent of women workers are married and rest of them are unmarried, divorced, widowed or abandoned by their husbands.

3) Level of Education: Female garment workers are less literate than their male counterpart. Many of them can only sign their name. Literacy rate among female workers (age 15+) is 56.8 that are higher than the total female literacy rate of our country (Paul-Majumder and Begum). In some cases women completed secondary and above education and doing better jobs than other women in garment industries.

4) Migration: 83 percent of female workers of garment sector are migrants from rural to urban areas. (Paul-Majumder and Begum, 2000. Many women are still migrating to the urban areas especially in Dhaka city to get a job in garment industry.

5) Poverty: There is no question about the poverty of female garment workers in Bangladesh. Rural poverty pushes them to Dhaka city to get a job in garment industries (After 2000). Their daily income is less than one US dollar (\$), in most cases.

6) Health and Nutrition: The health and nutrition conditions of women garment workers are very poor. Research has shown that over $40 \%$ of the female factory workers suffer from chronic diseases such as gastrointestinal and sexual transmitted infections(STls), reproductive tract infections(RTls), menstrual and blood pressure problems, anemia and problems related to family planning [Bayard Roberts, Marie Stopes Clinic Society(MSCS) 2001]. Women workers are not able to take proper nutritional diet due to their poor income.

7) Living Condition: About 90 percent of women garment workers lives in slams and squatters in Dhaka city (After.2000, www. Nadir.org). the rest of them are living in jam-packed situations where no proper municipal facility exists.

\section{Women Garment Workers}

Being the biggest contributor to the country's foreign exchange around 76 percent-and employing around 2.2 million people 80 percent of them women, the importance of nurturing a sector as vibrant and thriving as the garments industry, can be emphasized enough: With export of Ready Made Garment; (RMG) reaching 9.2 billion in 2007 and predictions of it rising 12 billion or more in the next two years, it is obvious that the industry is growing at an exponential speed. Greater demand for our garments abroad indicates the improvement in quality the products as well as greater customer confidence, which translates to further expansion of the industry, more employment, more consumers in the domestic market and a huge boost to the economy. However, there are many jolts and stumbles along the road to economic freedom and overcoming them will determine whether we can sustain the boom that is waiting to happen.

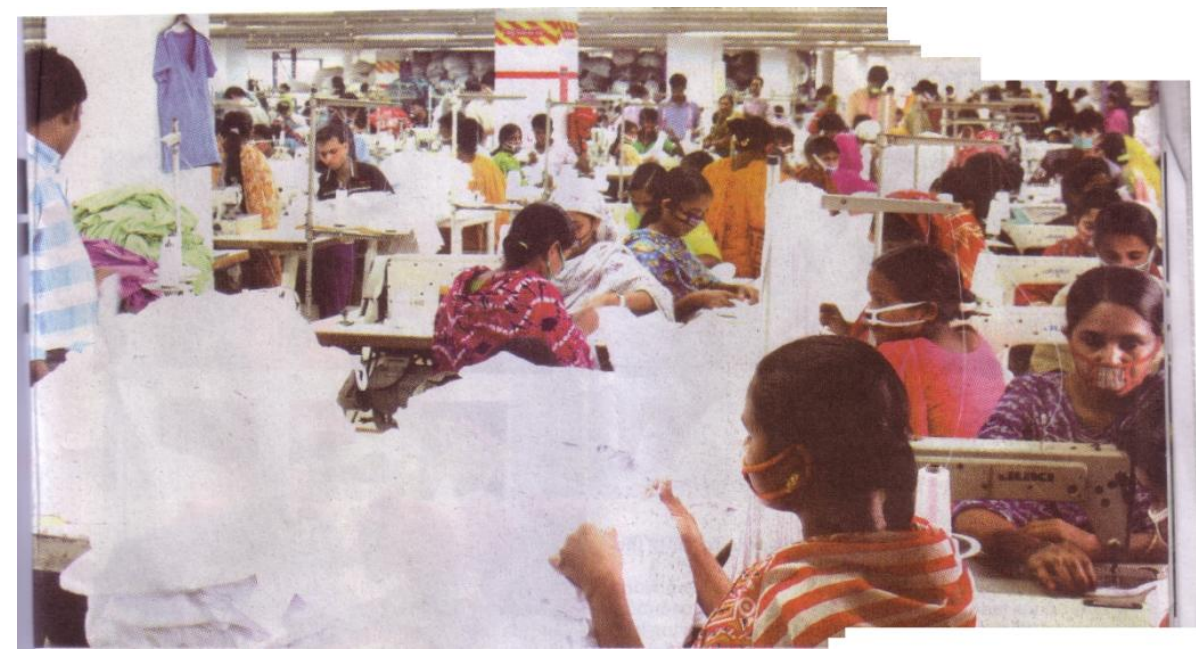



Analysis"

Marian Begum, a 27 year old garment worker in the Bangladesh capital says she has moved house three times this year with her two children. She shifted out of the first house because it was only a shelter in name, with no ventilation or toilet and no space for cooking, she says. But she was back house hunting for a third time before very long to escape the sexual advances of neighboring men. Now the young widow has rented a corner of the tin-shed home of a distant cousin. But at least "i am living in dignity and safety," Marian says. Rents are steep in Bangladesh. Even a tin-shed can be beyond the means of factory workers and daily wagers who earn like Marian about 2,000 takas (38 dollars) per month. Rural women who flock to the poorly-paying, monotonous and uncertain jobs in garment sweatshops in and around Dhaka end up living in squalid dormitory-type accommodation, 10 to 15 girls in one room.

The wretched living and working conditions take their toll of workers' health. A great majority of the estimated 1.5 million, mainly female, workers in some 3,000 garment factories across the country are at risk, according to several studies. Long factory working hours, between 10 and 12 hours and seven days a week, in addition to the burden of household work and bringing up children, make them more vulnerable to disease.

Nari Uddug Kendra or the women's initiative center, a non- governmental organization with links to the North-South Institute in Canada and the Canadian International Development Agency (CIDA) which conducted a study of 1,720 mainly women workers found convincing evidence of their health having worsened.

As many as 68 percent of the women complained of weakness and lethargy, which is related to long hours of work, according to doctors. The second most prevalent problem was gastric ulcers generally related to low incomes and irregular eating. Chest pain, backaches, eye trouble, headaches and joint pain were other common occupational ailments.

In addition women were found to be more prone to urinary infections, according to the study conducted in March - a direct result of their lack of access to toilets at work and restrictions on the number of times they are allowed to take short breaks. Nearly three quarters of the 43 garment factories covered by the study were found to be short of toilets for workers. In addition, only a third of factory owners paid workers to see a doctor if they were sick at the workplace, although the workers have to pay for the medicines themselves.

As a result the majority of workers said only when they were too ill to move did they take leave, while most women looked surprised when they were told that they were entitled to maternity leave under Bangladesh labour laws. Exploited at work, and living in wretched poverty, many women workers have succumbed to prostitution to make some extra money, another survey on sexual behavior of women and men in garment factories has revealed. Sexual harassment is common place in garment factories and women are threatened with dismissal if they speak out. The study conducted by Action Aid Bangladesh, a British NGO, estimates at least 20 percent of women workers were engaging in sex at the workplace.

Even the journey to and from the workplace is fraught with danger. Women workers run the risk of rape and harassment. The study revealed an alarming lack of awareness of safe sex practices and the likely spread of the HIV/AIDS disease. Sexually transmitted diseases (STD) are widespread. The number of infected people stood at 2.3 million at the end of 1996, according to official estimates.

The report also found a large number of young male workers - migrants from the country's villages in homosexual relationships, a taboo among orthodox Muslims. "Nothing tangible has been done to change our lot although a large chunk of the country's export earnings come from the garment sector," lamented Sheikh Nazma, president of the Bangladesh Independent Garment Sramik Union.

Asked what the Union's main demand was, she said housing was a major concern. "I think solution to the accommodation crisis is one of our major demands." Now workers are wondering if they should take seriously an assurance made by the Bangladesh Garments Manufacturers' and Exporters Association (BGMEA) whose president Mostafa Golam Quddus recently said factory owners had prepared a master plan to relocate to several areas outside Dhaka.

"We will construct 80 high-rise buildings for garment workers with an accommodation capacity of 4,000 families in each building," he said. 
Md. Riaduzzaman "Health and Nutritional Status of Female Garment Workers in Bangladesh: A Critical Analysis"

\section{Case Studies}

Case Study - 1

Name

Age

Marital status

Height

Weight

Educational Qualification

Monthly income
: $\quad$ Selina Parveen

$: \quad 20$

: $\quad$ Unmarried

: $\quad 150 \mathrm{~cm}$

$38.7 \mathrm{~kg}$

: Class ten

: $\quad 2300.00 \mathrm{Tk}$

Selina Parveen is garment worker. She comes from Kishorgonj. There are seven members in their family. She has one brother three sister. Her father is a small farmer. Her brother and one of her sister also work in garments. Two of her sisters go to school. She lives in a slum with her family far from the factory. Both Selina and her sister go to garments and their mother stay at home. They get up early in the morning. Her mother cooks food for them. After taking breakfast she starts to walk with other girls to the garment factory. Her duty is from $8 \mathrm{am}$ to $5 \mathrm{pm}$. When she was an SSC candidate she join in this job. She cannot participate in the exam because she was unable to manage the fees. Now she is earning money and she think that the life status and food quality has changed. Now she can eat better and nutritious food. Although she takes meat once in a month she takes some fish and vegetable every day. She also eats dry fish fruits and milk sometimes. She saves some money every day. As she is unmarried she dreamed to marry one day. She knows about the cost of marriage and dowry. As she knows that her father is unable to meet dowry demand so she saves some money. But she gives priority to her father and brother in taking nutritious food.

\section{Case Study - 2}

Name

Age

Height

Weight

Educational qualification

Monthly income

Marital status

\section{Najma}

22

$134 \mathrm{~cm}$

$37 \mathrm{~kg}$

: $\quad$ Primary

: $\quad 1600.00 \mathrm{Tk}$

: Widowed

Najma is a garment worker and widowed. She lives along with the family of other garment worker. She comes from Kishorgonj. She was getting marriage where she was 16 years old. Just after two years her husband was died. Then she came back to her father's house. But she didn't want to become a burden to her father. As a result she enters in a job. She is a female headed household. Her father is a day labour live in Kishorgonj. Her father come to her in every week with some vegetable and fish according to his ability. Najma don't go to market herself to buy food. She has no tension about taking nutritious food. She eat rice vegetable and fish. Other nutritious food like meat, milk, and fruit is very rare. She think as they are poor it is impossible for them to take nutritious food. They can eat only those items which are cheap in cost. She saves a large amount of money to meet the dowry demand of next marriage.

Case Study - 3

$\begin{array}{lll}\text { Name } & : & \text { Easmin } \\ \text { Age } & : & 25 \\ \text { Height } & : & 151 \mathrm{~cm} \\ \text { Weight } & : & 39 \mathrm{~kg} \\ \text { Educational qualification } & : & \text { Primary }\end{array}$


Md. Riaduzzaman "Health and Nutritional Status of Female Garment Workers in Bangladesh: A Critical Analysis"

Monthly income

Marital status

Husband's Name

$\begin{array}{ll}: & 1763.00 \mathrm{Tk} \\ : & \text { Married } \\ : & \text { Abdul Karim }\end{array}$

Easmin is a garment worker and she is married. At first they came here for her husband's work. Her husband is a fisherman. Now they have one daughter and one son. As their family becomes larger husband's income become inadequate for survive. As a result she becomes compelled to enter in a garment factory. She sends her daughter to her mother land the younger son is with her. In their factory crash facility is available. She takes her son with herself and keeps him in crash. As her husband is a fisherman they eat some fish every day and meat 2 days in a month. Other vegetable are available. Both they cook food together in morning and night. As Easmin go to garment she eat first and as the like to eat she eat more food than her husband. She save some money for contingency need and she want to buy some land for future.

\section{Case Study - 4}

Name

Age

Height

Weight

Educational qualification

Monthly income

Marital status

Husband's Name

\section{Aleya Khatun}

45

$163 \mathrm{~cm}$

$45 \mathrm{~kg}$

$\begin{array}{ll}: & \text { Primary } \\ : & 1662.00 \mathrm{Tk} \\ : & \text { Married } \\ : & \text { Arman }\end{array}$

Aleya is a garments worker and married. She has one son and five daughters. 2 of her daughter go to garment industry. She lives in a slum with her family. Her husband is a construction worker. As she has a large family it becomes difficult for her husband to bear the family. On the other hand 3 of their daughters become marriageable. There is a social evil exist in our society named dowry. Without dowry payment it is very difficult to marry for a girl. To earn and save some money she and 2 of her daughters enter in garment factory. There is a change in their lifestyle and food intake. They take fish 3-4 days in a week and meat one day in a month. Aleya give priority to the nutritional intake of her husband. She thinks that as her husband is a male and work hard more food and nutritious food is necessary for him. But Aleya do not any difference of food intake between her son and daughters. All are same. Aleya do all the household work. Her daughters help her. She save some money for the purpose of her daughter marriage.

\section{Case Study - 5}

Name

Age

Height

Weight

Educational qualification

Monthly income

Marital status

\author{
Shorna Jaman \\ 32 \\ $153 \mathrm{~cm}$ \\ $52 \mathrm{~kg}$ \\ MA \\ $1200.00 \mathrm{Tk}$ \\ Separated
}

Shorna Jaman also a garments worker. But she is employed in a higher rank. She is the Marketing manager of a factory. She has two sons and one daughter. When she was 21 years old she got marriage. Now she is separated from her husband because of some family cruelty. Her children are with her. She gets the maintenance cost of her children from their father. She has dream with her children. She wants to become them highly educated. She is a female headed household. She face double work burden. She gets up early in the morning land cook food for all. Maid servant helps her. She sends her children to school and go to the factory herself. Maid servant brings the children from school at noon, and cook food for lunch. Shorna come back at 5 PM. She helps her children in study. 
Md. Riaduzzaman "Health and Nutritional Status of Female Garment Workers in Bangladesh: A Critical Analysis"

She has tension about nutritious food for her children. But she is not aware about her nutritional necessity. It is also a result of socialization and result of work burden. She save some money is every month for future.

Questioner

\section{National Women Policy}

The Government of the People's Republic of Bangladesh declared National Women Development Policy in 8 March 1997, May 2004 and February 2008 to improve the conditions of women as a whole. The goal of the present women development policy is to improve the socioeconomic conditions of ill-standard women community of Bangladesh. To reach the target government takes some strategies. Government takes the strategies of investigations in working women fields, empowering workingwomen through participation, economic support, reduction of poverty, reducing violations against women, increasing health care and nutritional facilities, family planning and social welfare services, improving working environments, etc.

The provision of health and nutrition includes:

* Women should get proper nutrition

* Women should get proper education and training on nutrition.

* Women should involve in all sectors of health care including planning, distribution and preservation.

If national women development policy reaches its target the present conditions of workingwomen including garment workers of Bangladesh will improve significantly. (National Women's Policy 2008).

\section{RECOMMENDATIONS}

In recent years the garment industries in Bangladesh contributing a positive impact on the economic growth. At present 76.1 of the total national foreign exchange earnings are made by garment workers are female who are neglected in every share of life. More intensive and extensive research works should be undertaken to undertaken to understand and removes their problems. Entrance of the female into regular labour market cannot be checked due to progressive economic deterioration of the country but considerations could be made for improving their efficiency productivity and quality of life. Following recommendations may be made in this regard.

1. Interment of wage rate is advised as per international labour organization rules. Proper payment for the extra working hours should be ensured.

2. There should be shortening working hours as per labour law in our country.

3. There must be provision of mid-day meal free of cost or at a nominal rate for the female workers.

4. Provide free medical facilities for the garment workers.

5. Improving the working environment by installing central air condition or ventilation system, fire alarm, easy exists during emergency in the garment factory.

6. Wage rate should be settling according to the market price of commodity.

7. Insurance benefit must be ensured for the workers.

8. Improvement of nutritional knowledge through nutritional education programme among the female garment workers.

9. Long time sedentary work and less physical activity increase body fat percentage among them though their nutritional status are moderate which may cause future risk of cardiac deceases. So some physical exercises can be suggested to avoid the risk.

10. National women policy should be implemented properly to improve women's nutritional status.

\section{CONCLUSION}

Nutrition is very much essential for better health. It is a well-known says that women are weaker than men. But why they are weaker? Because of women's reproductive role women need more nutrition. But in a patriarchal society like ours women get less priority in all sectors as well as in nutritional 
Md. Riaduzzaman "Health and Nutritional Status of Female Garment Workers in Bangladesh: A Critical Analysis"

intake. The garments industries in Bangladesh are making a position impact on women's economic growth. We can expect that this economic growth can make a positive impact on women's nutritional awareness. Socialization process will not become major obstacle of it. Women will take their necessary nutrition and by the garments worker earn should be taken to improve the quality of life of their garments worker by providing adequate wages. The garment factories involve about 13 lack 20 thousand female and only 2 lack 80 thousand male workers. Insufficient nutrition and sleep and unhealthy working environment, inadequate sanitary facility in the working place and long working hours all these jointly affect a workers' health and working capacity. The result of this study confirms the existence of negative energy balance among the female garment workers.

\section{REFERENCES}

[1] Afsar, Rita, 2000. Rural-Urban Migration in Bangladesh: Causes, Consequences and Challenges. The University Press Limited, Dhaka.

[2] Aziz fahima, 1995, Nutrition, Health and labor Productivity: analysis of male and female Workers: A Test of the Efficiency Wage by hypothesis. University of MINNESOTA

[3] Asian Development Review, 1998. vol. 16 No. 2. Studies of Asian and Pacific Issues.

[4] Alah, M Ahmed, L and MD. Mostafizur Rahman 1993 "Nutritional dimension of Urban poverty in Bangladesh: a study of rural poor migrants in Dhaka city" vol.1 No.2 Bangladesh Urban Studies

[5] Bangladesh Institute of Development Studies (BIDS)'s report. Dhaka BBS, Bangladesh Demographic Health Survey 2004, BBS, Statistical Pocketbook, 2007 Bhasin kamla, 2000. 'Understanding Gender'. Kali for Women. New Delhi.

[6] C.Gopalan and Suminder Kaur (ed) 1989. Women and Nutrition in India. New Delhi.

[7] Food Intake and Energy Expenditure among the Adolescent Working Girls in a Garment Factory. 1993. Thesis Paper. Institution of Nutrition and Food Science. University of Dhaka.

[8] Hoque, Khondoker Bazlul, Murayama M, and S.M Mahfuzur Rahman. GARMENTS NDUSTRY IN BANGLADESH: its socio-economic implications. Series no-116 Institute of Development Studies.

[9] Hassan Sarwar and Easin Ali 1996 "Prospects of Health and Nutrition Interventions in SFDP Activities". Vol.26 no.1 The Journal of Rural Development.

[10] Haq Jahanara, Jahan Roushan and H.A. Begum 1985 "End-Decade National Women and Health." Organized by women for women and concerned women for family Planning. Women for Women.

[11] Joshi, A Shubhangini 2002. Nutrition and Deities. Tata McGraw-Hill, New York.

[12] Kabeer N and Mahmud. S (2004), "Globalization, garments and Poverty: Bangladeshi Garments worker in global and domestic markets". Journal of International Development, vol. no.1.

[13] Karim fahmida and Ahmed Lutfor, 1995. "Nutritional situation of the adolescent working girls in a city Garments factory." Vol. 2 Empowerment, a Journal of Women for Women.

[14] Khan Mohammad Shahin, Molla Manwar Hossain 2003. Social Security Measures for Women Garment Workers in Bangladesh: Present Scenario. Empowerment, A journal of Women for women. Vol 10.

[15] Khan, S, 1993. The Fifty Percent: Women in Development and Policy in Bangladesh. The University Press Limited, Dhaka.

[16] Lips M Hilary "Sex and Gender: An Introduction" second edition. Mayfield Publication. London.

[17] Mahmud Simeen and Hamid Shamim, 1990. “Women and Employment In Bangladesh” BIDS

[18] Mutry K Ranjani and Sankaren Lakshmi, 1999. "Denial and Distress: Gender Poverty \& Human Rights in Asia.” Zed Books, London, New York.

[19] Nutrition-A Scope, Publication- Upjohn Company

[20] Nutrition profile of the Destitute Women and Children in a selected Rehabilitation Centre in Gazipur. 2007. Thesis Paper. Institution of Nutrition and Food Science. University of Dhaka. 
Md. Riaduzzaman "Health and Nutritional Status of Female Garment Workers in Bangladesh: A Critical Analysis"

[21] Nutritional status with Dietary Habit lifestyle and Body Composition of urban female Garment workers. 2005. Thesis Paper. Institution of Nutrition and Food Science University of Dhaka.

[22] Nirzash, BRAC research paper 1997, February, part-4

[23] Nahar Firdousi and Sheikh S. Ahmed, 2007. Food Security and Diet Quality: Evidence from Bangladesh. Vol.24 no.4, Social Science.

[24] Oasmany S.R. (Ed) 1993.Nutrition and Poverty. Dhaka University Press Paul -Majumder, Pratima,Zohir .S.C 1991, "The Condition of Garments Worker in Bangladesh-An Appraisal. The Institute of BIDS.

[25] Paul -Majumder, Pratima, Zohir .S.C 1994, Dynamics of Wage employment: A Case of Employment in the Garments Industry. Vol. 22, June-Sept. No $2 \& 3$. The Bangladesh Development Studies.

[26] Paul -Majumder, Pratima, 1995, "Empowering women: Wage employment in Garments Industry." Empowerment, Journal of Women for Women, vol.2. Dhaka.

[27] Paul -Majumder, Pratima, 1996. "Health Impact of Women's Wage Employment: A case Study of the Garment Industry of Bangladesh". The Bangladesh development Studies(BDS),Quarterly journal Of Bangladesh Institute Of Development (BIDS), vol 26, no 1\&2, March-June, Dhaka.

[28] Paul -Majumder, Pratima and Zohir, Salma Chowdhuri, 1996. "Garment worker in Bangladesh: Economic Social and Health Condition." Research Monograph no 18.

[29] Pilcher Jane and Whelchan Imelda. 2004. "Fifty Key Concepts in Gender Studies". SAGE Publications ltd. London.

[30] Paul -Majumder, Pratima, Anwarw, 2000. The Gender Imbalance in the Export Oriented Industry in Bangladesh, Poverty Reduction and Economic Management Network. The World Bank.

[31] Paul - Majumder, Pratima (2003b) "Health Status of the Garment Worker in Bangladesh" Project report no 1. BIDS. Dhaka.

[32] Socio- Economic and Nutritional Status of selected Female Garments Worker in Bangladesh. 1995. Thesis Paper. Institution of Nutrition and Food Science. University of Dhaka.

[33] Sobhan, Rahman and Khundaker Nasreen (Ed), 2001. "Globalization and Gender: Changing Pattern of Women's Employment in Bangladesh." The University Press Limited. Dhaka

[34] Tinker Anne, Daly Patricia, Green cyclical, Saxenian H, L. Rana,and Gill Kirrin (ed) World Bank Discussion Papers. The World Bank. Washington D. C.

\section{AUTHOR'S BIOGRAPHY}

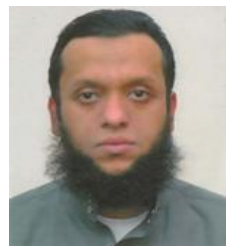

Md.Riaduzzaman, is a Lecturer and Head (In-Charge) of Department of Law of Daffodil International University. He received a LLB (Hon's) degree in from University of London. He also obtained LLB (Hon's) and LLM from University of Dhaka. His areas of specialization include human rights and development, media and information technology law, legal education and higher education. His research focuses on how social institutions interact with public policies to shape patterns of legal and social inequality. 